\title{
INFLUENCE OF INORGANIC OXIDANTS AND METAL IONS ON PHOTOCATALYTIC ACTIVITY OF PREPARED ZINC OXIDE NANOCRYSTALS
}

\author{
M.S. SEYED-DORRAJI ${ }^{1, *}$ \\ N. DANESHVAR ${ }^{1}$ \\ S. $A B E R^{2}$
}

Received: 19/03/08

Accepted: 17/10/08

\author{
${ }^{1}$ Department of Applied Chemistry, Faculty of Chemistry \\ University of Tabriz, Tabriz, Iran \\ ${ }^{2}$ Water and Wastewater Treatment Research Laboratory \\ Department of Applied Chemistry \\ Faculty of Chemistry, University of Tabriz, Tabriz, Iran
}

*to whom all correspondence should be addressed: e-mail: saeed_dorraji@yahoo.com

\section{ABSTRACT}

Zinc oxide nanocrystals were prepared by precipitation method using $\mathrm{ZnSO}_{4} \cdot 7 \mathrm{H}_{2} \mathrm{O}$ and $\mathrm{NaOH}$ as raw materials. The prepared $\mathrm{ZnO}$ nanocrystals were characterized by powder $\mathrm{X}$-ray diffraction (XRD). Primary objective was to focus on the influence of inorganic oxidants, metal ions and anions on photocatalytic activity of prepared $\mathrm{ZnO}$ nanocrystals. The study on the effects of oxidants such as $\mathrm{IO}_{4}^{-}, \mathrm{S}_{2} \mathrm{O}_{8}^{2-}, \mathrm{BrO}_{3}^{-}$and $\mathrm{ClO}_{3}^{-}$reveal that periodate ion is more efficient than others in improving the photocatalytic properties of $\mathrm{ZnO}$ nanocrystals. An investigation on the influence of metal ions on photocatalytic activity reveals that the removal of pollutant increases in the presence of $\mathrm{Fe}^{3+}$ and $\mathrm{Cu}^{2+}$. But negative effects are observed in the presence of anions. The possible roles of the additives on the reaction and the possible mechanisms of effect were discussed. The quantum yield $(\varphi)$ and electrical energy per order $\left(E_{E O}\right)$ were estimated and compared for UV/ZnO/Oxidant catalytic system.

KEYWORD: ZnO, Photocatalysis, electrical enrgy, quantum yield, metal ions, oxidants.

\section{INTRODUCTION}

The unique and fascinating properties of nanostructures materials have triggered tremendous motivation among the scientist to explore the possibilities of using them in a wide range of possible application such as photoelectronic energy conversion materials (Ishibashi and Fujishima 2000, Litter 1999) and water or air purification as friendly environmental photocatalysts (Evgenidou et al., 2005; Behnajady et al., 2006).

One material that has been in great interest from wide range of technological field associated with nanotechnology is zinc oxide ( $\mathrm{ZnO})$ (Guo et al., 2002). $\mathrm{ZnO}$ has been used in various applications such as photo-electric devices (Purica et al., 2001), electronic devices (Aoki et al., 2000), surface acoustic wave devices (Gorla et al., 1999), field emitters (Jo et al., 2003), sensors (Baruwati et al., 2006), ultraviolet lasers (Yan et al., 2003) and solar cells (Senoussaoui et al., 2004).

Also Zinc oxide, a II-VI semiconductor material with a large direct band gap (3.37 eV) and a relatively high exciton binding energy $(60 \mathrm{meV})$ at room temperature, has attracted considerable attention with respect to the degradation of various pollutants such as acid red 18 (Sobana and Swaminathan 2007), 4-nitrophenol (Parida et al., 2006), acridine orange (Pare et al., 2008), azo dye (Zhang et al., 2008) and so on, due to its being relatively cheap, chemical stability and high photocatalysis (Hong et al., 2006). However, the high degree of recombination of photogenerated electrons and holes in semiconductors decreased greatly their photocatalytic efficiency and impeded the practical application of photocatalytic technique in the degradation of contaminants in water and air. Thus, a major challenge in heterogeneous photocatalysis is the need to increase the charge separation efficiency of the 
photocatalyst and its photocatalytic efficiency. Therefore, the new developments of this technology have focused on searching for suitable compounds to enhance the photodegradation rates of organic substrates by quenching the conduction band electrons. The use of inorganic oxidants, for examples $\mathrm{S}_{2} \mathrm{O}_{8}^{2-}, \mathrm{IO}_{4}^{-}, \mathrm{BrO}_{3}^{-}$and $\mathrm{ClO}_{3}^{-}$in $\mathrm{UV} /$ photocatalyst system could increase the quantum efficiencies either by inhibiting electron-hole pair recombination through scavengering conduction band electrons at the surface of photocatalyst or offering additional oxygen atom as an electron acceptors to form the superoxide radical ion $\left(\mathrm{O}_{2}^{\circ-}\right)$. It has been observed that additional of some metal ions to aqueous photocatalyst dispersions improve UV/photocatalyst system's power in degradation of organic substrates.

In this research, we selected insecticide diazinon as the deputy of organic pollutants. Diazinon is an organophosphorous insecticide with wide spread agricultural and non-agricultural uses, acting by inhibition of acetylcholinesterase (Kouloumbos et al., 2003).

For practical application of wastewater treatment by UV/ZnO process, there is a need to determine the optimal conditions of experimental parameters for economic removal of the pollutant. Earlier, we have reported the effects of various parameters on the photocatalytic degradation of diazinon by UV/ZnO process (Daneshvar et al., 2007). From the previous studies, the optimum technological conditions for photocatalytic degradation of insecticide were obtained. Till now, many methods have been developed to synthesize zinc oxide nanocrystals including vapor phase growth (Sun et al., 2004), vapor-liquid-solid process (Gao and Wang 2004), sol - gel process (Kamalasanan and Chandra 1996), hydrothermal synthesis (Baruwati et al., 2006), flame spry pyrolysis (Mueller et al., 2003), thermal decomposition method (Yang and Chen 2004) and electrochemical deposition technique (Zheng et al., 2002). In the present work, we have successfully prepared the nanosized ZnO crystals by the precipitation method using sodium hydroxide as precipitating agent. Then, influences of inorganic oxidants, anions and metal ions on photocatalytic activity of prepared zinc oxide nanocrystals were investigated. The effectiveness of UV/ZnO/Oxidant systems in a laboratory-scale photoreactor will be compared by apparent quantum yield and electrical energy consumption. The possible roles of the additives on the reactions and the possible mechanisms of effect were discussed.

\section{EXPERIMENTAL}

\subsection{Materials}

Diazinon, an insecticide was purchased from Chem-service (USA) and used as received. The chemical structure of diazinon is given in Figure 1. The other chemicals used in this study such as $\left(\mathrm{NH}_{4}\right)_{2} \mathrm{~S}_{2} \mathrm{O}_{8}, \mathrm{KBrO}_{3}, \mathrm{KClO}_{3}, \mathrm{KIO}_{4}, \mathrm{Na}_{2} \mathrm{CO}_{3}, \mathrm{Na}_{2} \mathrm{SO}_{4}, \mathrm{NaHCO}, \mathrm{NaNO}_{3}, \mathrm{NaCl}$, $\mathrm{ZnSO}_{4} .7 \mathrm{H}_{2} \mathrm{O}, \mathrm{NaOH}, \mathrm{FeCl}_{3} .6 \mathrm{H}_{2} \mathrm{O}$ and $\mathrm{CuCl}_{2}$ were obtained from Merck Co. (Germany) and used as received. The distilled water used throughout the work.

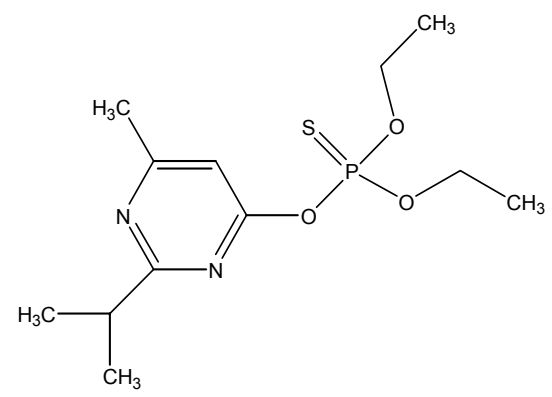

Figure 1. Chemical structure of insecticide diazinon (CAS number 333-41-5)

\subsection{Preparation of zinc oxide nanocrystals}

Nanometer oxide, $\mathrm{ZnO}$, was synthesized using the precipitation method. $\mathrm{ZnSO}_{4} \cdot 7 \mathrm{H}_{2} \mathrm{O}$ was used as the starting material and $\mathrm{NaOH}$ as precipitant without further purification. $\mathrm{NaOH}$ solution was added dropwise to the vigorously stirred solution to adjust $\mathrm{pH}$ to about 7 and a large amount of white slurry was formed. The resulting slurry was continuously stirred for 12 
$\mathrm{h}$, and then washed with deionized water. The wet powder was dried at about $100^{\circ} \mathrm{C}$ in air to form the precursor of $\mathrm{ZnO}$. Finally, the precursor was calcined in air at a certain temperature $\left(300^{\circ} \mathrm{C}\right.$ for 3 hours) to produce the nanosized $\mathrm{ZnO}$ photocatalyst.

Figure 2 illustrated the XRD pattern of $\mathrm{ZnO}$ nanocrystals prepared by precipitation method. The diffraction peaks of sample were quite similar to those of bulk $\mathrm{ZnO}$, which can be indexed as the hexagonal wurtzite structure $\mathrm{ZnO}$ and diffraction data were in agreement with JCPDS card of $\mathrm{ZnO}$ (JCPDS card No. 36-1451). No peaks other than ZnO were detected. Thus, the results showed that single phase hexagonal $\mathrm{ZnO}$ can be obtained. The crystallite size measurement were also carried out using the Scherrer equation, $D=k \lambda / \beta \cos \theta$, where $\mathrm{D}$ is the crystallite size, $\mathrm{k}$ is a constant ( $=0.89$ assuming that the particles are spherical), $\lambda$ is the wavelength of the X-ray radiation, $\beta$ is the line width (obtained after correction for the instrumental broading), and $\theta$ is the angle of diffraction. The average particle size obtained from the XRD data is $14 \mathrm{~nm}$.

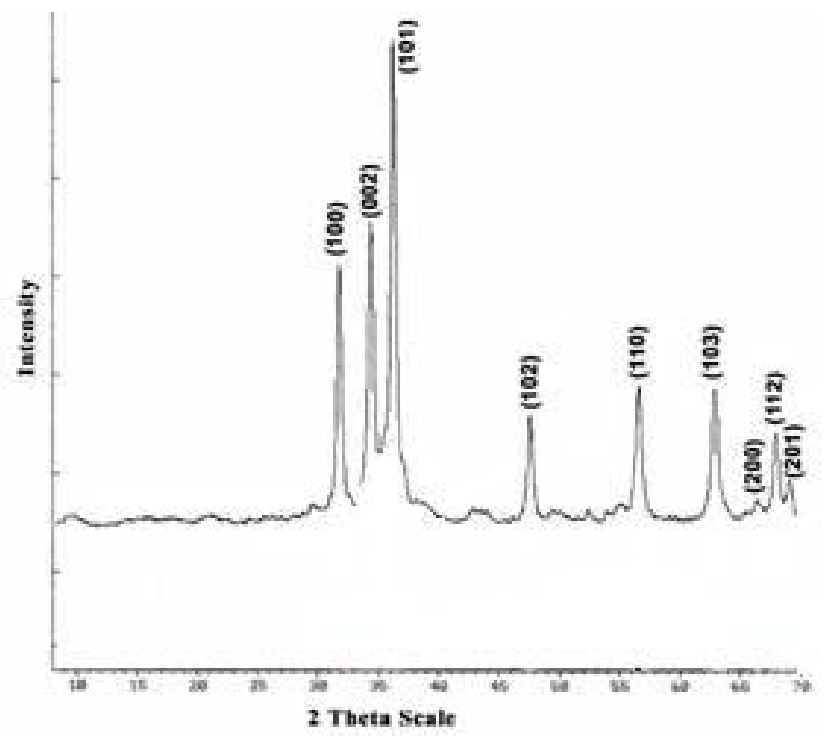

Figure 2. X-ray diffraction (XRD) pattern of synthesized $\mathrm{ZnO}$ nanocrystals

\subsection{Procedure and analysis}

At specific time intervals, suspension was sampled and samples were filtered through disks to remove $\mathrm{ZnO}$ nanoparticles. The concentration of insecticide in each sample was determined using a spectrophotometer (UV/Vis Spectrophotometer, Perkin-Elomer $550 \mathrm{SE}$ ) at $\lambda_{\max }=247$ $\mathrm{nm}$ and a calibration curve. Pseudo-first-order reaction has been widely and successfully used for the description of photocatalytic degradation of organic pollutants (Wong and Chu, 2003). The removal rates of diazinon in UVIZnO process is therefore expressed as:

$-\frac{\mathrm{d}[\mathrm{C}]}{\mathrm{dt}}=\mathrm{k}[\mathrm{C}] \quad \Leftrightarrow-\ln \left(\frac{\mathrm{C}}{\mathrm{C}_{0}}\right)=\mathrm{kt} \quad \Leftrightarrow[\mathrm{C}]=\left[\mathrm{C}_{0}\right] \exp (-\mathrm{kt})$

where $\left(C_{0}\right)$ is the initial concentration of insecticide, $(C)$ the concentration at timer $t$ and $k$ $\left(\mathrm{min}^{-1}\right)$ is the pseudo-first-order photocatalytic removal rate constant.

The half life time $\left(t_{1 / 2}\right)$ of the first-order reaction is the time required for the reactants to be degraded to half of their initial concentrations. The relationship between $t_{1 / 2}$ and $k$ is given by:

$\mathrm{t}_{\frac{1}{2}}=\frac{0.693}{\mathrm{k}}$

\section{RESULTS AND DISCUSSION}

\subsection{Influence of inorganic oxidants}

In the irradiated aqueous $\mathrm{ZnO}$ suspensions, oxygen on $\mathrm{ZnO}$ surface provides a natural sink for the photogenerated electrons. Hydroxyl radicals are then formed via the oxidation of $\mathrm{ZnO}$ 
surface-sorbed $\mathrm{H}_{2} \mathrm{O}$ or hydroxyl ions by the surviving holes. The introduction of a more effective electron acceptor than oxygen might be beneficial.

A group of oxidants utilized in this work is oxyhalogens, which have more than two oxygen atoms and one halogen atom $(\mathrm{Cl}, \mathrm{Br}$ or I) at the center of the molecule. The high polarizability in these oxidants makes their central atom electropositive, so that they can capture the electrons ejected from $\mathrm{ZnO}$.

\subsubsection{Effect of addition of $\mathrm{IO}_{4}^{-}$to $\mathrm{ZnO}$}

The effect of addition of periodate to $\mathrm{ZnO}$ for removal of the studied insecticide is shown in Figure 3. The enhancement of insecticide removal may be due to the scavenging of the photogenerated conduction band electrons of the excited $\mathrm{ZnO}$ which is more efficient than trapping with $\mathrm{O}_{2}$ as follows (Irmak et al., 2004):

$\mathrm{IO}_{4}^{-}+8 \mathrm{e}_{\mathrm{CB}}^{-}+8 \mathrm{H}^{+} \rightarrow 4 \mathrm{H}_{2} \mathrm{O}+\mathrm{I}^{-}$

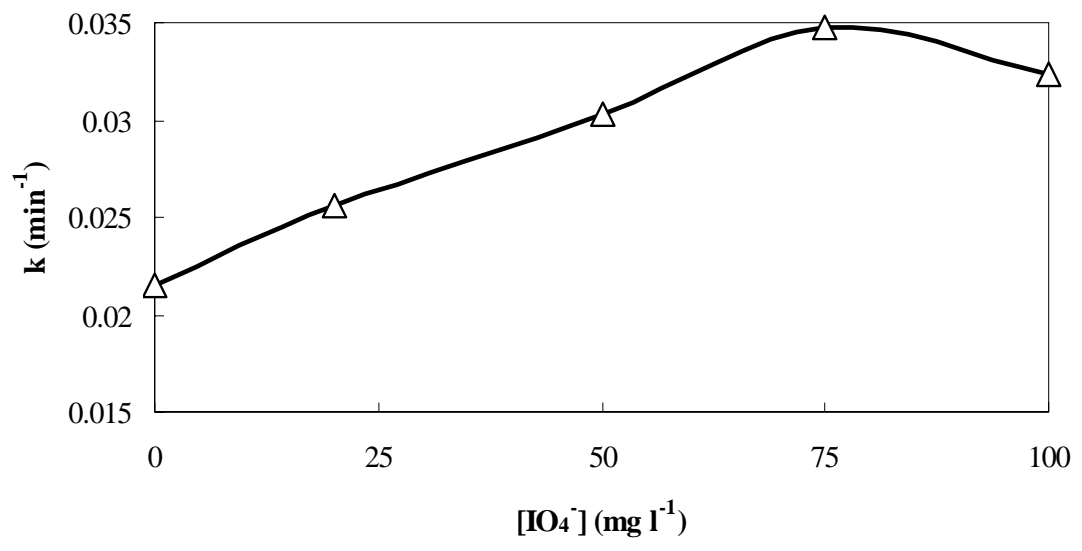

Figure 3. Effect of $\mathrm{IO}_{4}^{-}$addition on photocatalytic removal of insecticide $[\mathrm{ZnO}]=150 \mathrm{mg} \mathrm{l}^{-1} ;$ [Diazinon $]=20 \mathrm{mg} \mathrm{l}^{-1} ; \mathrm{pH}=$ neutral

Also the higher reactivity of $\mathrm{UV} / \mathrm{ZnO} / \mathrm{IO}_{4}^{-}$is due to the production of high reactive intermediate radicals such as $\mathrm{IO}_{3}^{\circ}, \mathrm{OH}^{\circ}$ and $\mathrm{IO}_{4}^{*}$. These radicals also assisted the degradation by free radical pathways. The photolysis of periodate in aqueous solution have been extensively studied and the simple reaction scheme as shown in Table 1 has been suggested (Lee and Yoon 2004). On further increase of $\mathrm{IO}_{4}^{-}$from 75 to $100 \mathrm{mg} \mathrm{I}^{-1}$ decreases the removal rate. This is due to adsorption effect of $\mathrm{I}^{-}$ion on $\mathrm{ZnO}$ surface, which affects the catalytic activity of $\mathrm{ZnO}$.

Table 1. Reaction mechanism for the periodate photolysis

\begin{tabular}{ll}
\hline \multicolumn{1}{c}{ Pathway I } & \multicolumn{1}{c}{ Pathway II } \\
\hline $\mathrm{IO}_{4}^{-}\left(\mathrm{I}^{\mathrm{VII}}\right)+\mathrm{hv} \rightarrow \mathrm{IO}_{3}^{\bullet}\left(\mathrm{I}^{\mathrm{VI}}\right)+\mathrm{O}^{\bullet-}$ & $\mathrm{IO}_{4}^{-}\left(\mathrm{I}^{\mathrm{VII}}\right)+\mathrm{h} v \rightarrow \mathrm{IO}_{3}^{-}\left(\mathrm{I}^{\mathrm{V}}\right)+\mathrm{O}\left({ }^{3} \mathrm{P}\right)$ \\
$\mathrm{O}^{\bullet-}+\mathrm{H}^{+} \Leftrightarrow \cdot \mathrm{OH}$ & $\mathrm{O}_{2}+\mathrm{O}\left({ }^{3} \mathrm{P}\right) \rightarrow \mathrm{O}_{3}$ \\
$\cdot \mathrm{OH}+\mathrm{IO}_{4}^{-} \Leftrightarrow \mathrm{OH}^{-}+\mathrm{IO}_{4}^{\cdot}$ & \\
$\mathrm{O}_{3}+\mathrm{IO}_{3}^{\cdot} \rightarrow \mathrm{IO}_{4}^{\cdot}+\mathrm{O}_{2}$ & \\
$2 \mathrm{IO}_{4}^{-} \Leftrightarrow \mathrm{I}_{2} \mathrm{O}_{8}$ & \\
$\mathrm{I}_{2} \mathrm{O}_{8}+\mathrm{H}_{2} \mathrm{O} \rightarrow \mathrm{IO}_{3}^{-}+\mathrm{IO}_{4}^{-}+2 \mathrm{H}^{+}+\mathrm{O}_{2}$ & \\
$2 \mathrm{IO}_{3}^{-} \Leftrightarrow \mathrm{I}_{2} \mathrm{O}_{6}$ & \\
$\mathrm{I}_{2} \mathrm{O}_{6}+\mathrm{H}_{2} \mathrm{O} \rightarrow \mathrm{IO}_{4}^{-}+\mathrm{IO}_{3}^{-}+2 \mathrm{H}^{+}$ & \\
\hline
\end{tabular}




\subsubsection{Influence of addition of $\mathrm{BrO}_{3}^{-}$on $\mathrm{ZnO}$}

The enhancement of removal rate in the $\mathrm{UV} / \mathrm{ZnO} / \mathrm{BrO}_{3}^{-}$system is due to the reaction between $\mathrm{BrO}_{3}^{-}$and $\mathrm{e}_{\mathrm{CB}}^{-}$. The effect of addition of $\mathrm{BrO}_{3}^{-}$on the photocatalytic removal of insecticide is shown in Figure 4. This reaction reduces the recombination of electron-hole pair (Poulios and Tsachpinis 1999).

$\mathrm{BrO}_{3}^{-}+6 \mathrm{e}_{\mathrm{CB}}^{-}+6 \mathrm{H}^{+} \rightarrow\left[\mathrm{BrO}_{2}^{-}, \mathrm{HOBr}\right] \rightarrow \mathrm{Br}^{-}+3 \mathrm{H}_{2} \mathrm{O}$

\subsubsection{Effect of addition of $\mathrm{ClO}_{3}^{-}$on $\mathrm{ZnO}$}

The effect of adding $\mathrm{ClO}_{3}^{-}$on the photocatalytic removal of diazinon has been investigated by varying the amount of $\mathrm{ClO}_{3}^{-}$from 0 to $100 \mathrm{mgl}^{-1}$. From Figure 5 , it is clear that the addition of $\mathrm{ClO}_{3}^{-}$increases the removal rate. The enhancement in UVIZnO process by the addition of $\mathrm{ClO}_{3}^{-}$is due to increased charge separation. This is done by accepting the conduction band electron (Choy and Chu, 2007).

$\mathrm{ClO}_{3}^{-}+6 \mathrm{e}_{\mathrm{CB}}^{-}+6 \mathrm{H}^{+} \rightarrow \mathrm{Cl}^{-}+3 \mathrm{H}_{2} \mathrm{O}$

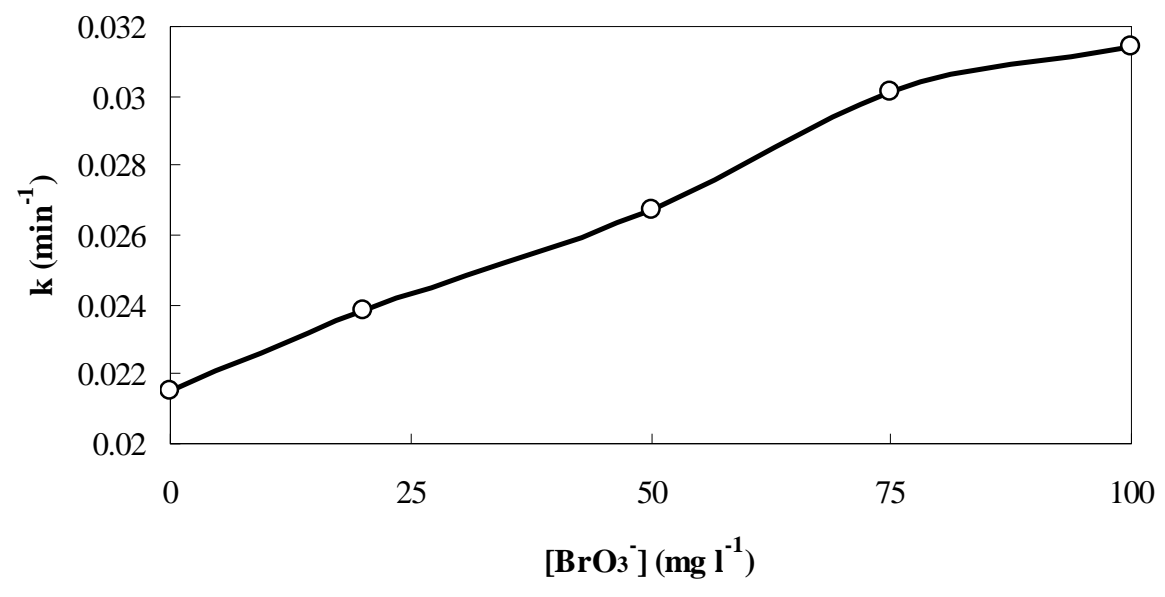

Figure 4. Effect of $\mathrm{BrO}_{3}^{-}$addition on photocatalytic removal of diazinon $[\mathrm{ZnO}]=150 \mathrm{mg} \mathrm{I}^{-1} ;$ [Diazinon $]=20 \mathrm{mg} \mathrm{l}^{-1} ; \mathrm{pH}=$ neutral

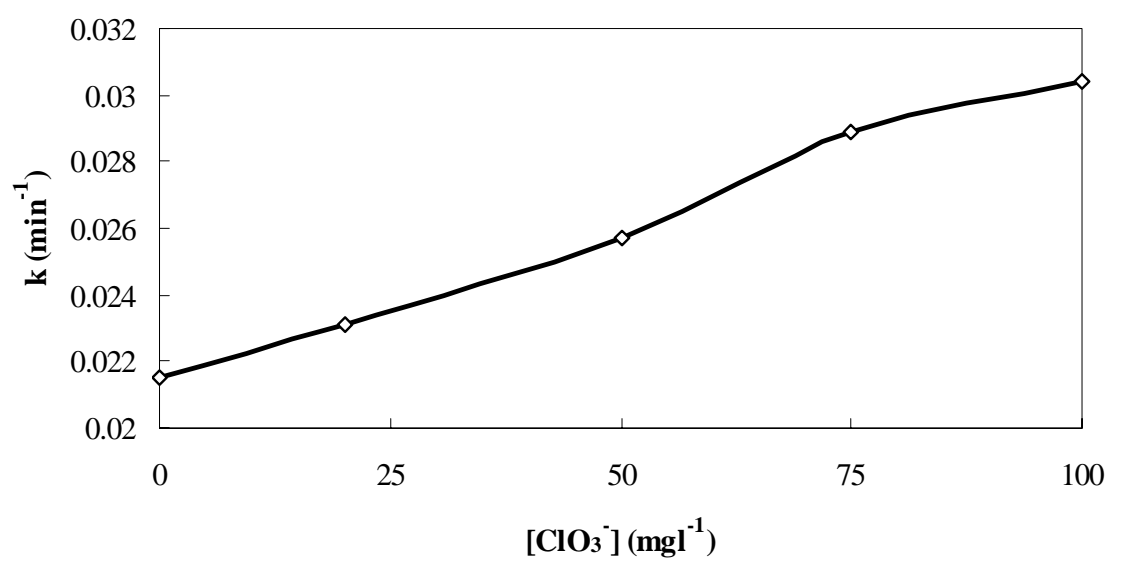

Figure 5. Effect of $\mathrm{ClO}_{3}^{-}$addition on photocatalytic removal of diazinon [ZnO]= $150 \mathrm{mg} \mathrm{I}^{-1}$; [Diazinon] $=20 \mathrm{mg} \mathrm{I}^{-1} ; \mathrm{pH}=$ neutral 


\subsubsection{Effect of addition of $\mathrm{S}_{2} \mathrm{O}_{8}^{2-}$ on $\mathrm{ZnO}$}

Figure 6 shows the effect of addition of peroxydisulfate to $\mathrm{ZnO}$ on removal of diazinon. The peroxydisulfate anions can trap the photogenerated conduction band electrons of $\mathrm{ZnO}$ more than $\mathrm{O}_{2}$, and generate strong oxidizing $\mathrm{SO}_{4}^{-\bullet}$ according to the following reaction (Sobana and Swaminathan 2007)

$$
\mathrm{S}_{2} \mathrm{O}_{8}^{2-}+\mathrm{e}_{\mathrm{CB}}^{-} \rightarrow \mathrm{SO}_{4}^{2-}+\mathrm{SO}_{4}^{-\bullet}
$$

Sulfate radicals anion is also generated at wavelength $254 \mathrm{~nm}$ and can participate in reactions with the solvent, according to the following reactions (Muruganandham and Swaminathan 2006)

$$
\begin{aligned}
& \mathrm{S}_{2} \mathrm{O}_{8}^{2-}+\mathrm{hv} \rightarrow 2 \mathrm{SO}_{4}^{-\cdot} \\
& \mathrm{SO}_{4}^{-\cdot}+\mathrm{H}_{2} \mathrm{O} \rightarrow{ }^{\cdot} \mathrm{OH}+\mathrm{SO}_{4}^{2-}+\mathrm{H}^{+}
\end{aligned}
$$

Sulfate radical does also react with $\mathrm{H}_{2} \mathrm{O}_{2}$ according to:

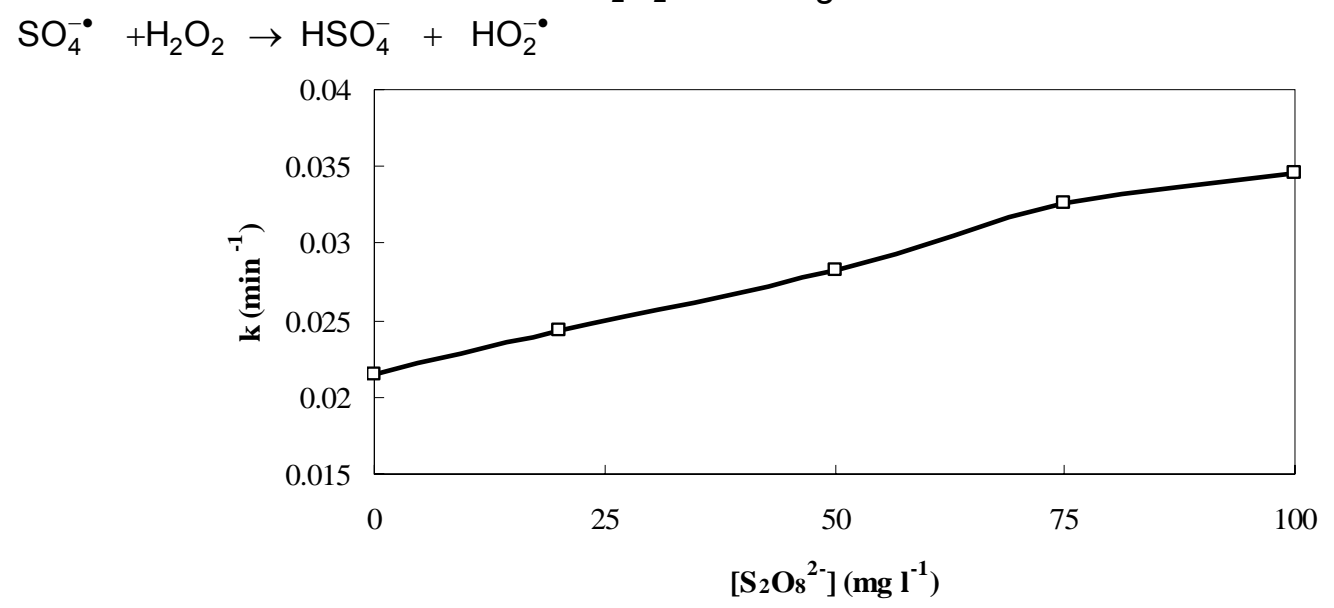

Figure 6. Effect of $\mathrm{S}_{2} \mathrm{O}_{8}^{2-}$ addition on photocatalytic removal of insecticide $[\mathrm{ZnO}]=150 \mathrm{mg} \mathrm{I}^{-1}$; [Diazinon] $=20 \mathrm{mg} \mathrm{l}^{-1} ; \mathrm{pH}=$ neutral

\subsection{Effect of metal ions}

The presence of dissolved metal ions is common in natural waters as well in industrial waters, and they can sensibly affect the rate and efficiency of photocatalytic reactions. The influence of added metal ions on photocatalytic removal is shown in Figure 7.

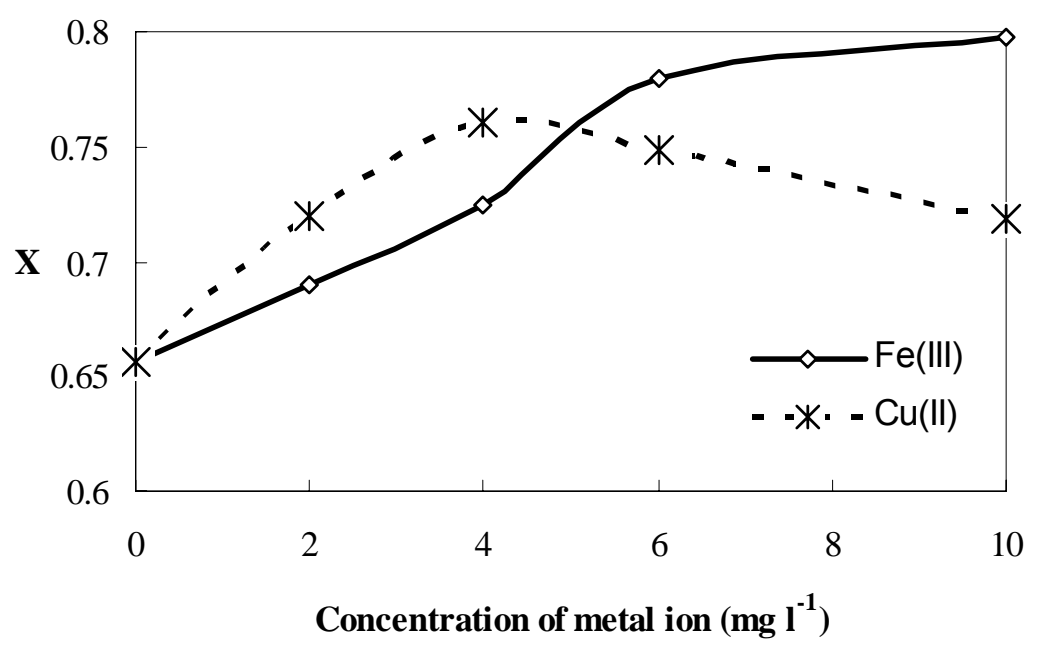

Figure 7. Effect of addition of metal ions on photocatalytic removal of diazinon [ZnO]= $150 \mathrm{mg} \mathrm{l}^{-1}$; [Diazinon] $=20 \mathrm{mg} \mathrm{l}^{-1} ; \mathrm{pH}=$ neutral; Irradiation time $=50 \mathrm{~min}$ 


\subsubsection{Effect of $\mathrm{Cu}^{2+}$}

The effect of adding $\mathrm{Cu}^{2+}$ on the photocatalytic removal efficiency of insecticide was investigated by varying the amount of $\mathrm{Cu}^{2+}$ from 0 to $10 \mathrm{mg} \mathrm{l}^{-1}$. From Figure 7 , it can be seen that adding a small amount of $\mathrm{Cu}^{2+}$ (up to $4 \mathrm{mg} \mathrm{l}^{-1}$ ) the photocatalytic removal efficiency of diazinon increases from 0.65 to 0.76 , but if the $\mathrm{Cu}^{2+}$ concentration is larger than $4 \mathrm{mg} \mathrm{l}^{-1}$, the photocatalytic removal efficiency decreases. $\mathrm{Cu}^{2+}$ behaves as electron scavenger, preventing the recombination of electron-hole pairs, thus increasing the chances of the formation of $\mathrm{OH}^{\bullet}$ on the $\mathrm{ZnO}$ surface (Ravichandran et al., 2007).

$$
\mathrm{Cu}^{2+}+\mathrm{e}_{\mathrm{CB}}^{-} \rightarrow \mathrm{Cu}^{+}
$$

This is favorable for the photocatalytic reactions. But when the $\mathrm{Cu}^{2+}$ concentration is higher, the photocatalytic removal efficiency decreases. It may be attributed to the low reduction potential for $\mathrm{Cu}^{2+} / \mathrm{Cu}^{+}$couple. As a result, $\mathrm{Cu}^{2+}$ ions are reduced to $\mathrm{Cu}^{+}$by electrons. While $\mathrm{Cu}^{+}$ions, thus formed are oxidized to $\mathrm{Cu}^{2+}$ by the photogenerated holes on the surface of $\mathrm{ZnO}$ nanoparticles or by $\mathrm{OH}^{\bullet}$ through the following reactions (San et al., 2002).

$$
\begin{aligned}
& \mathrm{Cu}^{+}+\mathrm{h}^{+} \rightarrow \mathrm{Cu}^{2+} \\
& \mathrm{Cu}^{+}+\mathrm{OH}^{\cdot}+\mathrm{H}^{+} \rightarrow \mathrm{Cu}^{+}+\mathrm{H}_{2} \mathrm{O}
\end{aligned}
$$

Therefore, above explanation $\mathrm{Cu}^{2+}-\mathrm{Cu}^{+}$cycle does not produce any $\mathrm{OH}^{\bullet}$. Furthermore, it causes a decrease in the concentration of $\mathrm{OH}^{*}$ in the photocatalytic system.

\subsubsection{Effect of $\mathrm{Fe}^{3+}$}

From Figure 7, it can be seen that adding a small amount of $\mathrm{Fe}^{3+}\left(0-10 \mathrm{mg} \mathrm{l}^{-1}\right)$ the removal efficiency of insecticide increases from 0.65 to 0.79 . Positively charged $\mathrm{Fe}^{3+}$ adsorbed on the $\mathrm{ZnO}$ surface is easily reduced by trapping electrons and the amount of recombining electronhole pairs thus decreases. It is favorable for the formation of $\mathrm{OH}^{\circ}$ on the surface of $\mathrm{ZnO}$ nanoparticles.

$$
\mathrm{Fe}^{3+}+\mathrm{e}_{\mathrm{CB}}^{-} \rightarrow \mathrm{Fe}^{2+}
$$

At the same time, there exist the following reactions:

$$
\begin{aligned}
& \mathrm{Fe}^{2+}+\mathrm{HO}_{2}^{\cdot}+\mathrm{H}^{+} \rightarrow \mathrm{Fe}^{3+}+\mathrm{H}_{2} \mathrm{O}_{2} \\
& \mathrm{Fe}^{2+}+\mathrm{H}_{2} \mathrm{O}_{2}+\mathrm{H}^{+} \rightarrow \mathrm{Fe}^{3+}+\mathrm{OH}^{\bullet}+\mathrm{H}_{2} \mathrm{O}
\end{aligned}
$$

The above equations are favorable for the formation of $\mathrm{OH}^{\bullet}$ (Chen and Liu, 2007). But when the $\mathrm{Fe}^{3+}$ concentration is higher, the $\mathrm{Fe}(\mathrm{OH})^{2+}$ ion likely exists as the predominant monomeric iron (III)-hydroxy complex, which is also a major light absorbing species (Chen and Cheng 1999)

\subsection{Influence of anions}

Wastewater contains not only organic contaminants but also considerable amount of inorganic anions such as nitrate, sulfate, carbonate, etc. Hence it is useful to study the influence of these ions on this photocatalytic process. Two possible influences of inorganic ions on the photocatalytic reaction are: (1) changing the ionic strength of reaction medium and (2) inhibition of catalytic activity of the photocatalyst. The effects of added inorganic ions on the removal of diazinon are shown in Figure 8 . The results clearly show that the addition of inorganic anions on the photocatalytic process decreases the removal rate. The inhibition effect of these ions is due to the reaction of these ions with holes and ${ }^{\circ} \mathrm{OH}$ (Eqs. (16)-(23)) (Ravichandran et al., 2007 ; Daneshvar et al., 2007 ; Wenhua et al., 2000). 


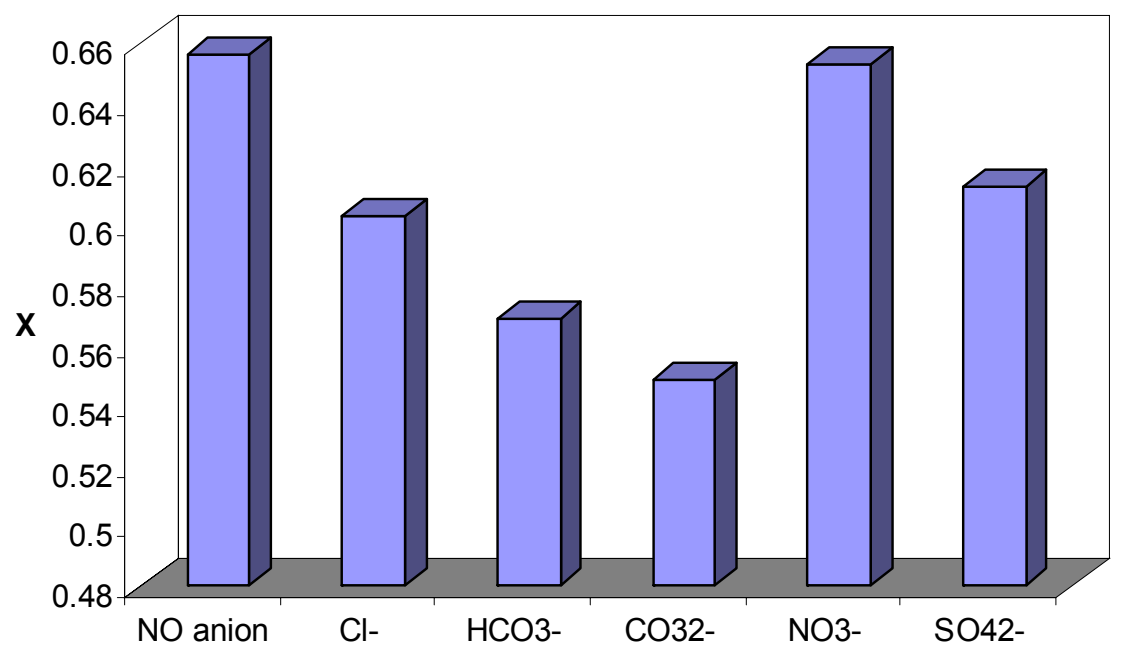

Figure 8. Effect of inorganic anions additions on the photocatakytic removal of insecticide. [ZnO]= $150 \mathrm{mg} \mathrm{l}^{-1}$; [Diazinon] $=20 \mathrm{mg} \mathrm{l}^{-1} ; \mathrm{pH}=$ neutral; Irradiation time=50 min

$$
\begin{aligned}
& \mathrm{SO}_{4}^{2-}+\mathrm{h}_{\mathrm{VB}}^{+} \rightarrow \mathrm{SO}_{4}^{-} \\
& \mathrm{SO}_{4}^{2-}+{ }^{\bullet} \mathrm{OH} \rightarrow \mathrm{SO}_{4}^{\cdot-}+\mathrm{OH}^{-} \\
& \mathrm{HCO}_{3}^{-}+{ }^{\bullet} \mathrm{OH} \rightarrow \mathrm{CO}_{3}^{--}+\mathrm{H}_{2} \mathrm{O} \\
& \mathrm{CO}_{3}^{2-}+{ }^{\bullet} \mathrm{OH} \rightarrow \mathrm{OH}^{-}+\mathrm{CO}_{3}^{\cdot-} \\
& \mathrm{Cl}^{-}+\mathrm{h}_{\mathrm{VB}}^{+} \rightarrow \mathrm{Cl}^{\bullet} \\
& \mathrm{Cl}^{\bullet}+\mathrm{Cl}^{-} \rightarrow \mathrm{Cl}_{2}^{--} \\
& { }^{\bullet} \mathrm{OH}+\mathrm{Cl}^{-} \Leftrightarrow \mathrm{HOCl}^{\bullet-} \\
& \mathrm{HOCl} l^{--}+\mathrm{H}^{+} \rightarrow \mathrm{Cl}^{\bullet}+\mathrm{H}_{2} \mathrm{O}
\end{aligned}
$$

Addition of $\mathrm{NO}_{3}^{-}$did not affect of the removal rate appreciably.

\subsection{Quantum yield}

The quantum yield of a reaction is defined as the number of diazinon molecules being decomposed per photon absorbed (Tsui and Chu 2001).

$$
\varphi=\frac{\text { Number of molecules decomposed }}{\text { Number of photons of light absorbed }}
$$

The photo decomposed rate constants $(k)$ of diazinon under the monochromatic light source can also be used for the calculation of its reaction quantum yield using Eq. (25) )Choy and Chu 2007, Wong and Chu 2003).

$$
\varphi=\frac{\mathrm{k}}{2.303 \mathrm{I}_{\circ} \varepsilon_{\lambda} l}
$$

where $\varphi$ is the reaction of quantum yield (dimensionless), $\mathrm{I}_{0}$ is the intensity of the incident light at $254 \mathrm{~nm}\left(2.33 \times 10^{-6}\right.$ Einstein $\left.\mathrm{I}^{-1} \mathrm{~s}^{-1}\right), \varepsilon_{\lambda}$ is the molar absorptivity of diazinon at $254 \mathrm{~nm}$ $\left(3558 \mathrm{~mol}^{-1} \mathrm{I} \mathrm{cm}^{-1}\right), \mathrm{I}$ is the cell length $(\mathrm{cm})$. The results of removal quantum yields by UV/ZnO/Oxidant are shown in Table 2.

\subsection{Electrical energy per order}

Although several reports are available in the literature on electrical energy determination of various AOPs, it is necessary to study the electrical energy consumption of the AOPs, under experimental conditions. Generally, the electrical energy consumption of AOPs, depends on number of experimental factors (type of pollutant being treated, configuration of the reactor, and type of light source used, etc.) and hence, electrical energy determination becomes important for the processes studied. A number of important factors such as economic, effluent quality, cost, etc., also play a vital role in selecting a waste treatment technology. Since 
photodegradation of aqueous organic pollutant is an electrical energy- related process, the electrical energy represents a major fraction of the operating costs. The figures of merit $\mathrm{E}_{\mathrm{EO}}$ allows for a rapid determination of the electrical energy cost and they indicate the total power required. For comparative purpose, the treatment efficiencies for $\mathrm{UV} / \mathrm{ZnO} / O x i d a n t$ processes are evaluated through the $E_{E O}$ values. The $E_{E O}$ is defined as the number of $\mathrm{kWh}$ of electrical energy required to reduce the concentration of pollutant by one order of magnitude $(90 \%)$ in 1 $\mathrm{m}^{3}$ of contaminated water. The $E_{E O}$ values were obtained from the inverse of the slope of a plot of $\log C / C_{o}$ versus UV dose. Considering first-order degradation kinetics, the UV doses were calculated for all processes using Eq. (26). From the UV doses, $\mathrm{E}_{\mathrm{EO}}$ can also be calculated using Eq. (27) (Bolton et al., 2001, Stephen et al., 2000)

Table 2. Electrical energy per order and quantum yield for photocatalytic removal of insecticide by different systems

\begin{tabular}{|c|c|c|c|c|}
\hline System & Concentration & $\begin{array}{c}t_{1 / 2} \\
(\min )\end{array}$ & $\begin{array}{c}\mathrm{E}_{\mathrm{EO}} \\
\left(\mathrm{kWhm}^{-3}\right)\end{array}$ & $\varphi$ \\
\hline UV & --- & 630 & 20000 & 0.0007 \\
\hline UVIZnO & $150 \mathrm{mg} \mathrm{l}^{-1}$ & 32.23 & 1075.3 & 0.013 \\
\hline \multirow{4}{*}{ UVIZnO $\left(150 \mathrm{mg} \mathrm{I}^{-1}\right) / \mathrm{S}_{2} \mathrm{O}_{8}^{2-}$} & $20 \mathrm{mg} \mathrm{l}^{-1}$ & 28.4 & 944.26 & 0.015 \\
\hline & $50 \mathrm{mg} \mathrm{l}^{-1}$ & 24.48 & 814.13 & 0.0176 \\
\hline & $75 \mathrm{mg} \mathrm{l}^{-1}$ & 21.25 & 706.74 & 0.0203 \\
\hline & $100 \mathrm{mg} \mathrm{l}^{-1}$ & 20.03 & 665.89 & 0.0216 \\
\hline \multirow{4}{*}{ UVIZnO $\left(150 \mathrm{mg} \mathrm{l}^{-1}\right) / \mathrm{IO}_{4}^{-}$} & $20 \mathrm{mg} \mathrm{l}^{-1}$ & 27.07 & 900 & 0.0159 \\
\hline & $50 \mathrm{mg} \mathrm{l}^{-1}$ & 22.87 & 760.39 & 0.0189 \\
\hline & $75 \mathrm{mg} \mathrm{l}^{-1}$ & 19.97 & 663.97 & 0.0216 \\
\hline & $100 \mathrm{mg} \mathrm{l}^{-1}$ & 21.39 & 711.1 & 0.0202 \\
\hline \multirow{3}{*}{ UVIZnO $\left(150 \mathrm{mg} \mathrm{l}^{-1}\right) / \mathrm{BrO}_{3}^{-}$} & $20 \mathrm{mg} \mathrm{l}^{-1}$ & 29.11 & 968.06 & 0.0148 \\
\hline & $50 \mathrm{mg} \mathrm{l}^{-1}$ & $\begin{array}{l}25.95 \\
2294\end{array}$ & $\begin{array}{l}862.92 \\
762.91\end{array}$ & $\begin{array}{l}0.0166 \\
0.0188\end{array}$ \\
\hline & $100 \mathrm{mg} \mathrm{l}^{-1}$ & 22.07 & 733.75 & 0.0195 \\
\hline \multirow{4}{*}{ UVIZnO $\left(150 \mathrm{mg} \mathrm{I}^{-1}\right) / \mathrm{ClO}_{3}^{-}$} & $20 \mathrm{mg} \mathrm{l}^{-1}$ & 30.13 & 1001.74 & 0.0143 \\
\hline & $50 \mathrm{mg} \mathrm{l}^{-1}$ & 26.96 & 896.49 & 0.0160 \\
\hline & $75 \mathrm{mg} \mathrm{l}^{-1}$ & 24.06 & 800 & 0.0179 \\
\hline & $100 \mathrm{mg} \mathrm{l}^{-1}$ & 22.71 & 755.16 & 0.0190 \\
\hline
\end{tabular}

UV dose $=\frac{\text { Lamp power }(\mathrm{kW}) \times \text { Time }(\min ) \times 1000}{\text { Treated volume }(\mathrm{I}) \times 60}$

$E_{E O}=\frac{U V \text { dose }}{\log \left(C_{\circ} / C\right)}$

The results are presented in Table 2. The electrical energy consumption for insecticide diazinon is in the following order $U V>U V / Z n O>U V / Z n O / \mathrm{ClO}_{3}^{-}>U V / Z n O / \mathrm{BrO}_{3}^{-}>\mathrm{UV} / \mathrm{ZnO}$ $/ \mathrm{S}_{2} \mathrm{O}_{8}^{2-}>\mathrm{UV} / \mathrm{ZnO} / \mathrm{IO}_{4}^{-}$. The higher electrical energy consumption means lower process efficiency. The $\mathrm{E}_{\mathrm{EO}}$ values revealed that increase of rate constant lowers the consumption of electrical energy.

\section{CONCLUSION}

From this experimental study, several conclusions can be made:

1) Addition of oxidants such as $\mathrm{S}_{2} \mathrm{O}_{8}^{2-}, \mathrm{IO}_{4}^{-}, \mathrm{BrO}_{3}^{-}$and $\mathrm{ClO}_{3}^{-}$increase the photocatalytic activity significantly.

2) Among the oxidants periodate ion is found to be more efficient than others.

3) Addition of $\mathrm{Cu}^{2+}$ and $\mathrm{Fe}^{3+}$ increased the photocatalytic removal of insecticide

4) The apparent quantum yield $(\varphi)$ was calculated for UV/ZnO/Oxidant catalytic systems and was highest for periodate. 
5) The EE/O values of UV/ZnO/Oxidant systems could be arranged as follow: $\mathrm{UV} / \mathrm{ZnO} / \mathrm{ClO}_{3}^{-}>\mathrm{UV} / \mathrm{ZnO} / \mathrm{BrO}_{3}^{-}>\mathrm{UV} / \mathrm{ZnO} / \mathrm{S}_{2} \mathrm{O}_{8}^{2-}>\mathrm{UV} / \mathrm{ZnO} / \mathrm{IO}_{4}^{-}$.

\section{ACKNOWLEDGEMNET}

The first author wishes to thank the office of exceptional talent of University of Tabriz for the financial support.

\section{REFERENCES}

Aoki T., Hatannaka Y., Look D.C., (2000), ZnO diode fabrication by excimer-laser doping, Appl. Phys. Lett., 76, 3257-3258.

Baruwati B., Kumar D.K., Manorama S.V., (2006), Hydrothermal synthesis of highly crystalline $\mathrm{ZnO}$ nanoparticles: comparative sensor for LPG and EtOH, Sens. Actuators B: Chem., 119, 676-682

Bolton J.R., Bircger K.G., Tumas W., Tolman C.A., (2001), Figure-of-merit for the technical development and application of advanced oxidation technologies for electric and solarderived systems, Pure Appl. Chem., 73, 627-637.

Chen S.F., Cheng X.L., (1999), Photocatalytic reduction of dichromate by titanium dioxide supported on hollow glass microbeads, Chin. J. Chem., 17, 419-424.

Chen S., Liu Y., (2007), Study on the photocatalytic degradation of glyphosate by $\mathrm{TiO}_{2}$ photocatalyst, Chemosphere, 67, 1010-1017.

Choy W.K., Chu W., (2007), The use of oxyhalogen in photocatalytic reaction to remove Ochloroaniline in $\mathrm{TiO}_{2}$ dispersion, Chemosphere, 60, 2106-2013

Daneshvar N., Aber S., Seyed-Dorraji M.S., Khataee A.R., Rasoulifard M.H., (2007), Photocatalytic degradation of the insecticide diazinon in the presence of prepared nanocrystalline $\mathrm{ZnO}$ powders under irradiation of UV-C light, Separation and purification Technology, 58, 91-98.

Evgenidou E., Futianos K., Poulios I., (2005), Semiconductor-sensitized photodegradation of dichlorvos in water using $\mathrm{TiO}_{2}$ and $\mathrm{ZnO}$ as catalysts, Appl. Catal. B, 59, 81-89.

Gao P.X., Wang Z.L., (2004), Nanopropeller arrays of zinc oxide, Appl. Phys. Lett., 84, 2883-2885.

Gorla C.R., Emanetoglu N.W., Liang S., (1999), Structural optical and surface acoustic wave properties of epitaxial $\mathrm{ZnO}$ film grown on (011 over-bar 2) sapphire by metalorganic chemical vapor deposition, J. Appl. Phys., 85, 2595 -2602.

Guo Y.L., Ji Y.L., Xu H., (2002), Regularly shaped, single-crystalline $\mathrm{ZnO}$ nanorods with wurtzite structure, J. Am. Chem. Soc. Commun., 124, 14864-14865.

Hong R-Y., Pan T-T., Qian J-Z., Li H-Z., (2006), Synthesis and surface modification of ZnO nanoparticles, Chem. Eng. J., 19, 71- 81.

Irmak S., Kusvuran E., Erbatur O., (2004), Degradation of 4-chloro-2-mthyl phenol in aqueous solution by UV irradiation in the presence of titanium dioxide, Appl. Catal. B, 54, 85-91.

Ishibashi K. and Fujishima A., (2000), Quantum yields of active oxidative species formed on $\mathrm{TiO}_{2}$ photocatalyst, J. Photochem. Photobiol. A, 134, 139-142.

JO S.H., Lao J.Y., Ren Z.F., (2003), Field-emission studies on thin films of zinc oxide nanowires, Appl. Phys. Lett., 83, 4821 - 4823.

Kamalasanan M.N., Chandra S., (1996), Sol - gel synthesis of ZnO thin film, Thin Solid Films, 288, 112-115.

Kouloumbos V.N., Tsipi D.F., Hiskia A.F., Nikolic D., Breemen R.B.V., (2003), Identification of photocatalytic degradation product of diazinon in $\mathrm{TiO}_{2}$ aqueous suspensions using GC/MS/MS and LC/MS with quadrupole time-of-flight mass spectroscopy, J. Am. Soc. Mass Spectrom., 14, 803-817.

Lee C., Yoon J., (2004), Application of photoactivated periodate to the decolorization of reactive dye: reaction parameters and mechanism, J. Photochem. Photobiol. A, 165, 35-41.

Litter M.I., (1999), Heterogeneous photocatalysis: Transition metal ions in photocatalytic systems, Appl. Catal. B, 23, 89-114.

Mueller R., Madler L., Pratsinis S.E., (2003), Nanoparticle synthesis at high production rates by flame spray pyrolysis, Chem. Eng. Sci., 58, 1969-1976.

Muruganandham M. and Swaminathan M., (2006), $\mathrm{TiO}_{2}$-UV photocatalytic oxidation of Reactive Yellow 14: effect of operational parameters, J. Hazrd. Mater., 135, 78-86. 
Pare B., Jonnalagadda B., Tomar H., Singh P., Bhagwat V.W., (2008), ZnO assisted photocatalytic degradation of acridine orange in aqueous solution using visible irradiation, Desalination, 232, 80-90.

Parida K.M., Dash S.S., Das D.P., (2006), Physico-chemical characterization and photocatalytic activity of zinc oxide prepared by various method, J. Colloid Interface Sci., 298, 787-793.

Poulios I., Tsachpinis I., (1999), Photodegradation of the textile dye reactive black 5 in the presence of semiconducting oxides, J. Chem. Technol. Biotechnol., 74, 349-357.

Purica M., Budianu E., Rusu E., (2001), ZnO thin film on semiconductors materials substrate for large area photo-detector applications, Thin solid Films, 383, 284 -286.

Ravichandran L., Selvam K., Swaminathan M., (2007), Effect of oxidants and metal ions on photodefluoridation of penta fluorobenzoic acid with $\mathrm{ZnO}$, Separation and Purification Technology, 56, 192-198.

San N., Hatipoglu A., Kocturk G., Cinar Z., (2002), Photocatalytic degradation of 4-nitrophenol in aqueous $\mathrm{TiO}_{2}$ suspensions: Theoretical prediction of the intermediates. J. Photochem. Photobiol. A, 146, 189-197.

Senoussaoui N., Krause M., Muller J., (2004), Thin-film solar cells with periodic grating couple, Thin Solid Films, 451-452, 397-401.

Sobana N., Swaminathan M., (2007), The effect of operational parameters on the photocatalytic degradation of acid red 18 by ZnO, Separation and Purification Technology, 56, 97-103.

Stephen C., Stefan M.I., Bolton J.R., Safarzadeh A., (2000), UV/ $\mathrm{H}_{2} \mathrm{O}_{2}$ treatment of methyl tert-butyl ether in contaminated waters, Environ. Sci. Technol., 34, 659-662.

Sun X.C., Zhang H.Z., Xu J., (2004), Shape controllable synthesis of ZnO nano-rod arrays via vapor phase growth, Solid state Commun., 129, 803- 807.

Tsui S.M., Chu W., (2001), Quantum yield of the photodegradation of hydrophobic dye in the presence of acetone sensitizer, Chemosphere, 44, 17-22.

Wenhua L., Hong L., Suoan C., Jianging Z., Chunan C., (2000), kinetics of photocatalytic decolorization of aniline in water over $\mathrm{TiO}_{2}$ supported on porous nickel, J. Photochem. Photobiol. A, 131, 125-132.

Wong C.C. and Chu W., (2003), The direct photolysis and photocatalytic degradation of alachlor at different $\mathrm{TiO}_{2}$ and UV sources, Chemosphere, 50, 981-987.

Yan H.Q., He R.R., Johnson J., (2003), Dendritic nanowire ultraviolet laser array, J. Am. Chem. Soc., 125, 4728-4729.

Yang Y. and Chen H., (2004), Size control of $\mathrm{ZnO}$ nanoparticles via thermal decomposition of zinc acetate coated on organic additives, J. Cryst. Growth, 263, 447-453.

Zhang Z., Yuan Y., Liang L., Cheng Y., Shi G., Jin L., (2008), Preparation and photoelectrocatalytic activity of $\mathrm{ZnO}$ nanorods embedded in highly ordered $\mathrm{TiO}_{2}$ nanotube arrays electrode for azo dye degradation, J. Hazard. Mater., 158, 517-522.

Zheng M.J., Zhang L.D., Li G.H., Shen W.Z., (2002), Fabrication and optical properties of largescale uniform zinc oxide nanowire arrays by one-step electrochemical deposition technique, Chem. Phys. Lett., 363, 123-128. 